\title{
Abundance and Taxonomic Composition \\ of Bacterioplankton in Freshwater Lake Gusinoye (Buryatia) in the Warm Water Zone of the Gusinoozerskaya Thermal Power Plant
}

\author{
Bayarma V. Tsydenova ${ }^{a}$, Olga P. Dagurova*a, \\ Valentina P. Garankina ${ }^{a}$, Vyacheslav B. Dambaeva, \\ Dmitry V. Matafonov ${ }^{b}$ and Olga A. Baturina ${ }^{c}$ \\ ${ }^{a}$ Institute of General and Experimental Biology SB RAS \\ 6 Sakhyanovoi Str., Ulan-Ude, 670047, Russia \\ ${ }^{b}$ The Baikalian Branch of Gosrybcenter FSBSI \\ 4 b Khakhalova Str., Ulan-Ude, 670034, Russia \\ 'Institute of Chemical Biology and Fundamental Medicine SB RAS \\ 8 Lavrentiev Ave., Novosibirsk, 630090, Russia
}

Received 06.10.2018, received in revised form 07.11.2018, accepted 10.12.2018

The abundance and taxonomic composition of bacterioplankton was determined in different parts of Lake Gusinoye, which is the largest freshwater lake in Buryatia (Russia) and is used as a cooling reservoir for the Gusinoozerskaya thermal power plant (TPP). The lake is also used as a public water supply and for commercial fishing. The chemical composition of water in the warm water discharge channel did not differ from that in the lake. The total number of bacteria in the water ranged from 0.1 to 2.5 million cells $/ \mathrm{ml}$; the maximum counts of bacterial cells were obtained close to the mouth of the Zagustai River, where household effluents are discharged. Seasonal dynamics showed an increase in bacterial numbers that corresponded with the spring peak of phytoplankton development in May. The maximum numbers of organotrophic bacteria were observed in the warm water discharge channel, the point of its influx into the lake and near the inflowing rivers' mouths. There were no significant differences between the number of bacteria in the zones subjected to and those not subjected to the thermal impact of the power plant. However, total abundance and numbers of organotrophic bacteria were higher in the warm water discharge channel and in the mouth areas of the rivers. This observation suggests that a "barrier zone" with increased number and activity of microorganisms, typical of river mouths, may also be formed in the discharge channel. The patterns of bacterioplankton diversity in the parts of the lake exposed to the thermal pressure were similar. The phyla Cyanobacteria (average 28\%), Actinobacteria (average 28\%) and Proteobacteria (average 22\%), Firmicutes (average 9\%) and Bacteroidetes (average 7\%)

(C) Siberian Federal University. All rights reserved

This work is licensed under a Creative Commons Attribution-NonCommercial 4.0 International License (CC BY-NC 4.0).

* Corresponding author E-mail address: dagur-ol@mail.ru 
dominated. The peculiarity of the taxonomic composition of this community was the dominance of the phyla Cyanobacteria and Actinobacteria, which indicates that production and destruction processes can be intensified.

Keywords: bacterioplankton, Lake Gusinoye, cooling reservoir, taxonomic composition, bacterial number, $16 S$ metagenomics.

Citation: Tsydenova B.V., Dagurova O.P., Garankina V.P., Dambaev V.B., Matafonov D.V., Baturina O.A. Abundance and taxonomic composition of bacterioplankton in freshwater Lake Gusinoye (Buryatia) in the warm water zone of the Gusinoozerskaya thermal power plant. J. Sib. Fed. Univ. Biol., 2018, 11(4), 356-366. DOI: 10.17516/1997-1389-0078.

\title{
Численность и таксономический состав
}

\section{бактериопланктона в пресном озере Гусиное (Бурятия) \\ в зоне влияния теплых вод Гусиноозерской ГРЭС}

\author{
Б.В. Цыденова ${ }^{a}$, О.П. Дагурова ${ }^{a}$, В.П. Гаранкина ${ }^{a}$, \\ В.Б. Дамбаев ${ }^{a}$, Д.В. Матафонов ${ }^{\tilde{0}}$, О.А. Батурина ${ }^{\mathrm{B}}$ \\ ${ }^{a}$ Институт общей и экспериментальной биологии СО РАН \\ Россия, 670047, Улан-Удэ, ул. Сахьяновой, 6 \\ ${ }^{\circ}$ Байкальский филиал ФГБНУ «Госрыбиентр» \\ Россия, 670034, Улан-Удэ, ул. Хахалова, $4 б$ \\ ${ }^{8}$ Институт химической биологии \\ и фундаментальной медичины СО РАН \\ Россия, 630090, Новосибирск, пр. Ак. Лаврентьева, 8
}

Определены численность и таксономический состав бактериопланктона в различных участках крупнейшего в Республике Бурятия пресного озера Гусиное, которое является водоемомохладителем Гусиноозерской ГРЭС, также используется для хозяйственно-питьевого водоснабжения и в рыбохозяйственных иелях. По химическому составу вод не выявлено отличий между сбросным каналом теплых вод и акваторией озера. Общая численность бактерий в воде озера колебалась от 0.1 до 2.5 млн. кл/мл, максимальные значения выявлень около устья реки Загустай, где происходит сброс очищенных сточных бытовых вод. В сезонной динамике наблюдалось увеличение численности почти на всех станциях в мае, в весенний пик развития фитопланктона. Максимальная численность органотрофных бактерий обнаружена в сбросном канале теплых вод и месте впадения сбросного канала в озеро, а также в местах вблизи впадения в озеро рек. Явных различий по показателям численности бактерий между зоной теплового влияния ГРЭС и зоной, не подверженной тепловому влиянию, не наблюдалось. Можно отметить увеличение численности микроорганизмов в термальном сбросном канале и в участках около устьев рек. Возможно, в сбросном канале образуется «барьерная зона», характерная для устьев рек и характеризующаяся увеличением численности и активности микроорганизмов. Разнообразие бактериопланктона в участках озера, подвергаюшихся 
тепловому прессу, было схожим. В составе сообщества доминировали представители филумов Cyanobacteria (в среднем 28\%), Actinobacteria (в среднем 28\%) и Proteobacteria (в среднем 22\%), Firmicutes (в среднем 9\%) и Bacteroidetes (7\%). Особенностью таксономического состава сообщества было доминирование филумов Cуапоbacteria и Actinobacteria, что указывает на возможную интенсификацию процессов продукиии и деструкции.

Ключевые слова: бактериопланктон, озеро Гусиное, водоем-охладитель, таксономический состав, численность, 16S метагеномика.

\section{Introduction}

Bacteria play an important role in the functioning of freshwater reservoirs and in maintaining the processes involved in water self-purification. They are the foundation of biogeochemical barriers and can also be used as bioindicators of ecosystem changes (Zavarzin, Kolotilova, 2001; Falkowski et al., 2008). To predict changes in ecosystems caused by human activities, it is important to study microorganisms in lakes and river mouths.

Lake Gusinoye is one of the biggest freshwater bodies in Buryatia and is located in Selenga Middle Mountains. The area of the lake is $164 \mathrm{~km}^{2}$; the drainage basin has an area of $924 \mathrm{~km}^{2}$. It is classified as a water body with a low flow rate and slow water exchange. There are nine rivers which make up the primary inflow, with the river Bain-Gol being the only primary outflow (Borisenko et al., 1994).

Since the mid-70s of the $20^{\text {th }}$ century, when the Gusinoozerskaya thermal power plant (TPP) started operating, the lake has been used as a natural cooler and therefore has been subjected to significant anthropogenic impact (atmospheric emissions by the station, a warm water inflow from the power station cooling system, wastewater discharges from Gusinoozersk and the village of Gusinoye Ozero). Lake Gusinoye is also used for commercial fishing and as a public water supply. Approximately one-fourth of the overall water is extracted from the lake yearly for the purposes of supplying the community (Borisenko et al., 1994). Due to the thermal impact, the ice cover in the northern part of the lake does not form in winter, thus disrupting seasonality of the processes that would otherwise occur in the water.

There is lack of data concerning the microbial composition of Gusinoye Lake. To date, the study of microorganisms has covered only cultivated physiological groups of bacteria (Khakhinov et al., 2005; Abidueva et al., 2014).

The aim of this work was to determine the abundance and biodiversity of bacterioplankton in different parts of Lake Gusinoye and to evaluate the impact of thermal pollution on the bacterial community.

\section{Materials and Methods}

Water samples for hydrochemical and microbiological analysis were collected at 11 stations; six stations are located in the area of thermal influence in the northern part of the lake, two are in the central part, and three are in the southern part of the lake.

At station 1 (TPP cooling system water intake), we collected samples of the water that is pumped from the depth of $17 \mathrm{~m}$ into the supply channel and fed to the cooling units of the power plant. After cooling the power plant units, warm water flows to the discharge channel. Water was sampled at the beginning of the discharge channel (St. 2), in the discharge channel (St. 3) 
and at the point where the channel enters the lake (St. 4). Samples were also taken near the mouths of the rivers Teli (St. 7), Zagustay (St. 8), TsaganGol (St. 10), and next to the point of the BainGol River outflow (St. 11). Station 8 was located near the Zagustay River mouth, where effluent wastewaters are discharged from Gusinoozersk. Station 5 was located close to the railway station Baraty and station 9 near the Halbogin coal mine; they were both examined as areas subjected to anthropogenic impact. Station 6, located in the central part of the lake, was used as a control (Fig. 1).

To determine the total number of bacteria, water was sampled at all 11 stations in May 2014, June 2015, October 2015, and April 2016. The chemical composition of the water was determined at eight stations in April 2016. To analyse the bacterial community composition, water was sampled at five stations (St. 1, 2, 3, 5, 7) located within the area of thermal impact in June and October 2015.

Samples for hydrochemical and microbiological analyses were collected from the surface of the lake into sterile glassware. Temperature and $\mathrm{pH}$ were measured using the portable device 'PH- 200' (HM Digital, China). The concentration of dissolved oxygen was analysed using the Winkler method (Romanenko, Kuznetsov, 1974). Water hardness and anion/ cation concentrations were determined by titration.

To determine the total number of bacteria, $30 \mathrm{ml}$ of water was filtered using a nitrocellulose membrane filter with pore diameter of $0.2 \mu \mathrm{m}$ and dyed with $2.5 \%$ erythrosine. Next, the number of bacterial cells was counted using the Axiostar plus microscope (Carl Zeiss, Germany). The number

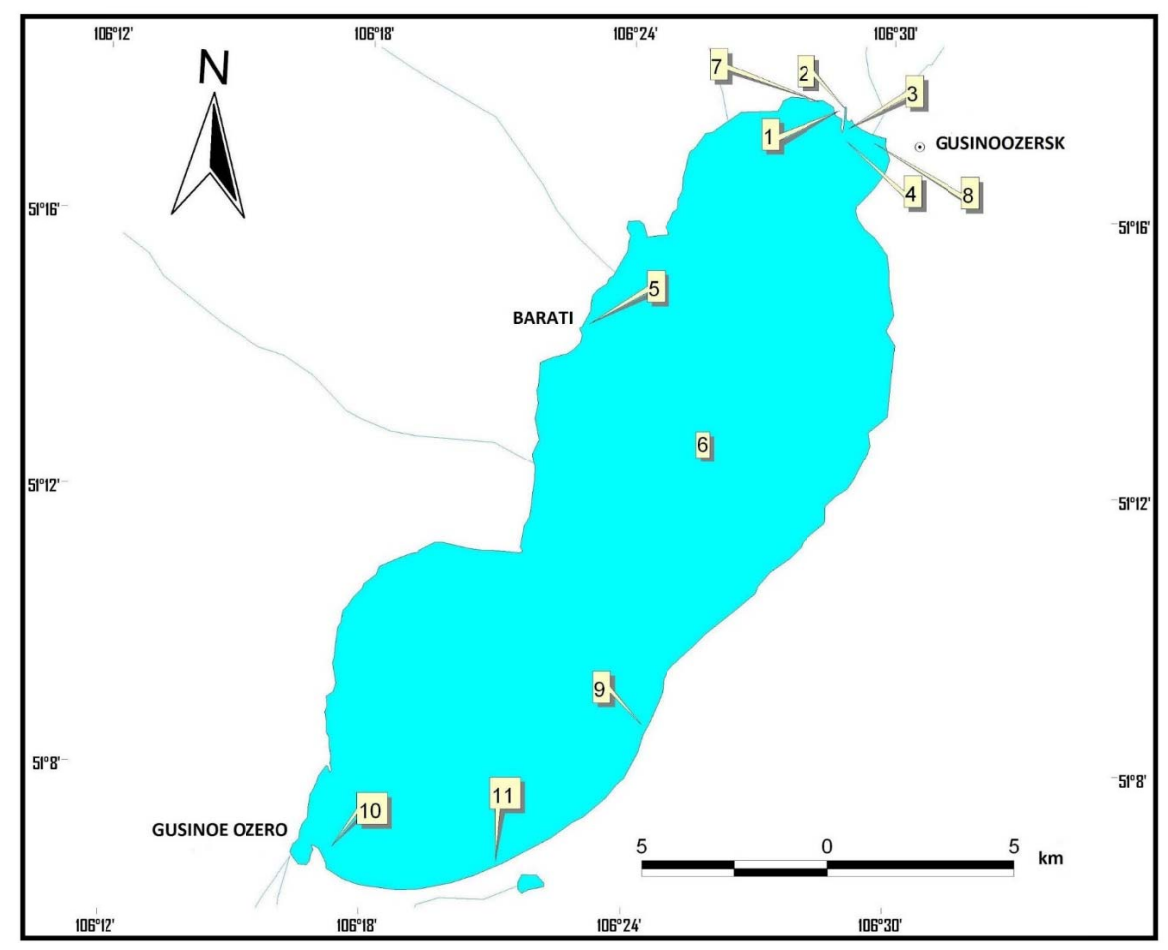

Fig. 1. Locations of sampling stations at Lake Gusinoye: 1 - water intake, 2 - warm water discharge, 3 - discharge channel, 4 - influx to the lake, 5 - at railway station Baraty, 6 - centre of the lake, 7 - mouth of the Teli River, 8 mouth of the Zagustay River, 9 - at Holbodzhinskiy coal mine, 10 - mouth of the Tsagan-Gol River, 11 - outflow of the Bain-Gol River 
of organotrophic bacteria was detected using Fish Peptone agar diluted 10-fold. Production and destruction of organic matter were analysed by the Winberg method, based on formation and utilisation of free oxygen (Romanenko, Kuznetsov, 1974).

For DNA extraction, approximately 500-ml water samples were concentrated using nitrocellulose membrane filters with pore diameter of $0.22 \mu \mathrm{m}$; filtration continued until the filter was clotted with bacterial suspension. DNA extraction from the filters was performed using the commercial kit NucleoSpin Soil (Macherey-Nagel, Germany). DNA sequencing was performed on MiSeq sequencer (Illumina) using Reagent Kit v3 (2x300, Illumina) in SB RAS Genomics Core Facility (Institute of Chemical Biology and Fundamental Medicine SB RAS). V3-V4 region of 16S rRNA gene was amplified using 343F (5'-CTCCTACGGRRSGCAGCAG-3') and 806R (5'-GGACTACNVGGGTWTCTAAT-3') primers containing adapter (Illumina), linker and barcode sequences (Fadrosh et al., 2014). Amplification was performed as described elsewhere (Martemyanov et al., 2016). Obtained paired sequences were analysed with UPARSE scripts (Edgar, 2013) using USEARCH v10.0.240 (Edgar, 2010). The bioinformatical analysis included overlapping of paired reads, filtering by quality and length, recognising identical sequences, rejecting singletons, deleting chimaeras, clustering and obtaining OTUs. Taxonomical classification of OTUs was performed using RDP Classifier 2.11 (Wang et al., 2007).

\section{Results}

\section{Physicochemical indicators}

In April, the temperature of the water in the ice-free discharge channel $\left(13.5^{\circ} \mathrm{C}\right)$ was much higher compared to the water in the lake $\left(2.0-3.9^{\circ} \mathrm{C}\right)$ (Table 1). Close to the exit of the discharge channel, the temperature declined insignificantly to $12.8^{\circ} \mathrm{C}$. The amount of dissolved substances (determined as a sum of anions and cations) was 404 to $449 \mathrm{mg} / \mathrm{dm}^{3}$, with the maximum value at the Bain-Gol River outflow. The water was alkalescent ( $\mathrm{pH}$ 7.2-8.8), with the $\mathrm{pH}$ maximum at the point of the warm water discharge. The amount of dissolved oxygen was high (up to $16 \mathrm{mg} / \mathrm{dm}^{3}$ ).

The chemical composition of the water in the discharge channel and in the lake was similar (Table 2). The type of water was determined as sulphate-hydrocarbonate-sodium. The maximum concentration of hydrocarbonates was $235 \mathrm{mg} / \mathrm{dm}^{3}$, sodium $69 \mathrm{mg} / \mathrm{dm}^{3}$, calcium $33 \mathrm{mg} / \mathrm{dm}^{3}$, magnesium $27 \mathrm{mg} / \mathrm{dm}^{3}$. A high concentration of sulphates (up to $77 \mathrm{mg} / \mathrm{dm}^{3}$ ) was found. The maximum amount of dry residue dependent on the total content of organic and mineral compounds was $332 \mathrm{mg} / \mathrm{dm}^{3}$, indicating that the water from the lake is suitable for drinking and household purposes (the maximum level of dry residue permitted for drinking water is $1000 \mathrm{mg} / \mathrm{dm}^{3}$ ). Based on the total water hardness value, the water in the lake is 'soft' (the maximum level permitted for drinking water is $7 \mathrm{meq} / \mathrm{L}$ ) as stated by Sanitary Rules and Regulations of the Russian Federation (2.1.4.1074-01).

\section{Abundance of microorganisms}

The total number of microorganisms in the water of the lake varied from 0.1 to 2.5 million cells per $\mathrm{ml}$ at different time periods. Maximal counts were detected near the Zagustay River mouth (St. 8), where the effluent wastewaters are discharged (Fig. 2). Relatively high total numbers of microorganisms were detected at the stations exposed to anthropogenic impact, namely, near the point of warm water discharge, in the vicinity of the Baraty railway station and at the Teli River mouth. Seasonal dynamics revealed an increase 
Table 1. Physicochemical characteristics of the water of Lake Gusinoye (April 2016)

\begin{tabular}{|c|c|c|c|c|c|c|c|c|}
\hline Station & Coordinates & $\mathrm{D}, \mathrm{m}$ & $\mathrm{pH}$ & $\mathrm{t},{ }^{\circ} \mathrm{C}$ & $\mathrm{M}, \mathrm{mg} / \mathrm{dm}^{3}$ & $\mathrm{O}_{2}, \mathrm{mg} / \mathrm{L}$ & $\begin{array}{c}\mathrm{P}, \mathrm{mg} \mathrm{C} / \mathrm{m}^{3} \\
\text { per day }\end{array}$ & $\begin{array}{c}\mathrm{D}, \mathrm{mg} \mathrm{C} / \mathrm{m}^{3} \\
\text { per day }\end{array}$ \\
\hline 1 & $\begin{array}{l}51^{\circ} 17.695^{\prime} \\
106^{\circ} 28.807^{\prime}\end{array}$ & 0.6 & 8.45 & 6.4 & 408.2 & 10.9 & 3.7 & 7.4 \\
\hline 2 & $\begin{array}{l}51^{\circ} 17.661^{\prime} \\
106^{\circ} 28.885^{\prime}\end{array}$ & 0.5 & 8.80 & 13.5 & 403.8 & 12.2 & 11.1 & 14.8 \\
\hline 3 & $\begin{array}{l}51^{\circ} 17.300^{\prime} \\
106^{\circ} 28.930^{\prime}\end{array}$ & 1.6 & 8.12 & 12.8 & 404.7 & 10.2 & 11.1 & 14.8 \\
\hline 4 & $\begin{array}{l}51^{\circ} 17.300^{\prime} \\
106^{\circ} 28.828^{\prime}\end{array}$ & 4.0 & 8.33 & 5.1 & - & 9.6 & - & - \\
\hline 5 & $\begin{array}{l}51^{\circ} 14.539^{\prime} \\
106^{\circ} 23.079^{\prime} \\
\end{array}$ & 2.4 & 8.54 & 2.2 & 422.5 & 13.4 & 7.4 & 11.1 \\
\hline 6 & $\begin{array}{l}51^{\circ} 12.494^{\prime} \\
106^{\circ} 24.951^{\prime}\end{array}$ & 22 & 8.46 & 2.0 & 425.6 & 12.8 & 3.7 & 0.1 \\
\hline 7 & $\begin{array}{l}51^{\circ} 17.702^{\prime} \\
106^{\circ} 28.035^{\prime}\end{array}$ & 2.0 & 8.33 & 5.1 & - & 8.9 & - & - \\
\hline 8 & $\begin{array}{l}51^{\circ} 17.202^{\prime} \\
106^{\circ} 29.328^{\prime}\end{array}$ & 2.1 & 8.53 & 10.6 & - & 8.9 & - & - \\
\hline 9 & $\begin{array}{l}51^{\circ} 08.340^{\prime} \\
106^{\circ} 24.347^{\prime}\end{array}$ & 2.3 & 8.50 & 2.0 & 433.5 & 16.0 & 7.4 & 14.8 \\
\hline 10 & $\begin{array}{l}51^{\circ} 06.648^{\prime} \\
106^{\circ} 17.475^{\prime}\end{array}$ & 2.9 & 7.20 & 2.2 & 416.2 & 10.6 & 3.7 & 18.5 \\
\hline 11 & $\begin{array}{l}51^{\circ} 06.592^{\prime} \\
106^{\circ} 20.970^{\prime}\end{array}$ & 2.0 & 7.65 & 3.9 & 449.3 & 12.6 & 7.4 & 7.4 \\
\hline
\end{tabular}

$\mathrm{D}$ - depth, $\mathrm{M}$ - sum of mineral compounds dissolved, $\mathrm{P}$ - organic production, $\mathrm{D}$ - organic destruction, dash - no analysis was performed.

Table 2. Chemical composition of the water of Lake Gusinoye (April 2016)

\begin{tabular}{|c|c|c|c|c|c|c|c|c|c|}
\hline Station & $\begin{array}{c}\mathrm{Na}^{+}, \\
\mathrm{mg} / \mathrm{L}\end{array}$ & $\begin{array}{c}\mathrm{Ca}^{2+}, \\
\mathrm{mg} / \mathrm{L}\end{array}$ & $\begin{array}{c}\mathrm{Mg}^{2+}, \\
\mathrm{mg} / \mathrm{L}\end{array}$ & $\begin{array}{c}\mathrm{HCO}_{3}^{-}, \\
\mathrm{mg} / \mathrm{L}\end{array}$ & $\begin{array}{c}\mathrm{NO}_{3}^{-}, \\
\mathrm{mg} / \mathrm{L}\end{array}$ & $\begin{array}{c}\mathrm{SO}_{4}^{2-}, \\
\mathrm{mg} / \mathrm{L}\end{array}$ & $\begin{array}{c}\mathrm{Cl}^{-}, \\
\mathrm{mg} / \mathrm{L}\end{array}$ & $\begin{array}{c}\text { Dry } \\
\text { residue, } \\
\mathrm{mg} / \mathrm{L}\end{array}$ & $\begin{array}{c}\text { Water } \\
\text { hardness, } \\
\mathrm{meq} / \mathrm{L}\end{array}$ \\
\hline 1 & 60.26 & 27.05 & 18.24 & 213.56 & 0.38 & 65.8 & 18.8 & 301.5 & 2.85 \\
2 & 56.75 & 27.05 & 19.46 & 213.56 & 0.29 & 63.5 & 18.8 & 297.0 & 2.95 \\
3 & 57.90 & 27.05 & 18.85 & 213.56 & 0.35 & 63.3 & 18.8 & 297.9 & 2.90 \\
5 & 59.46 & 33.07 & 17.02 & 219.66 & 0.38 & 69.1 & 18.8 & 312.7 & 3.05 \\
6 & 64.09 & 29.06 & 17.63 & 216.61 & 0.26 & 74.7 & 18.4 & 317.3 & 2.90 \\
9 & 62.31 & 18.04 & 27.36 & 234.92 & 0.55 & 67.4 & 18.4 & 316.1 & 3.15 \\
10 & 68.99 & 31.06 & 17.63 & 222.72 & 0.43 & 53.5 & 17.0 & 304.8 & 0.55 \\
11 & 66.67 & 22.04 & 24.93 & 234.92 & 0.14 & 77.2 & 18.8 & 331.9 & 0.65 \\
\hline
\end{tabular}

in the number of microorganisms at almost all the stations in May, which coincided with the spring peak in phytoplankton development. The maximum number of organotrophic bacteria was observed in the discharge channel and at the point of its influx into the lake (Fig. 3). Higher numbers of microorganisms were also observed at the mouths of the Zagustay and Tsagan-Gol Rivers, at the point of the Bain-Gol River outflow and near the Baraty station. 


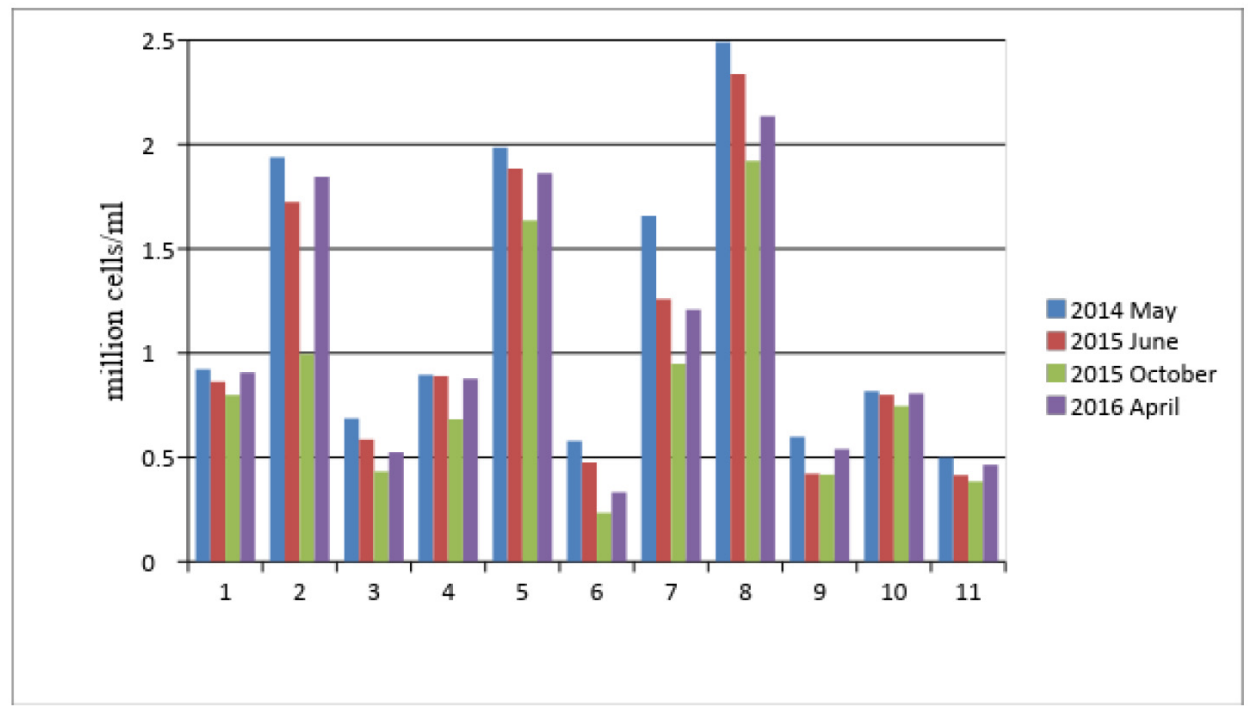

Fig. 2. Total abundance of microorganisms in the surface waters of Lake Gusinoye, cells/ml

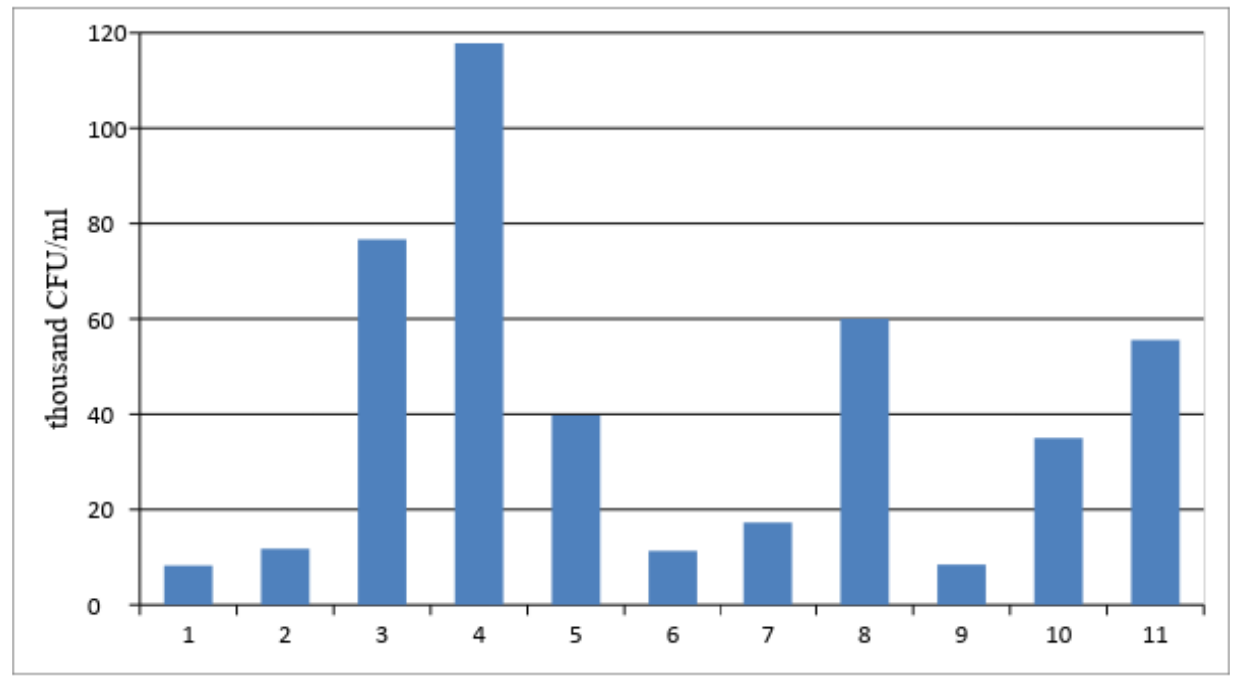

Fig. 3. Mean abundance of organotrophic bacteria in the surface waters of Lake Gusinoye, CFU/ml

\section{Bacterioplankton taxonomical composition}

The dominant phyla in bacterioplankton communities at all the stations were Cyanobacteria (approximately 28\%), Actinobacteria (approximately 28\%) and Proteobacteria (approximately 22\%) (Fig. 4). Phyla Firmicutes (approximately 9\%) and Bacteroidetes (7\%) were also represented in significant amounts. At the Teli River mouth a high amount of Cyanobacteria
$(60 \%)$ was observed, which may indicate that intensive production processes occur in the river estuaries. The composition of the microbial community at the point of warm water discharge from the Gusinoozerskaya TPP was similar to the composition observed in other sampled areas. The biodiversity of the communities was assessed using the Chaol index, which varied from 50 to 260. The values of the Chaol index 


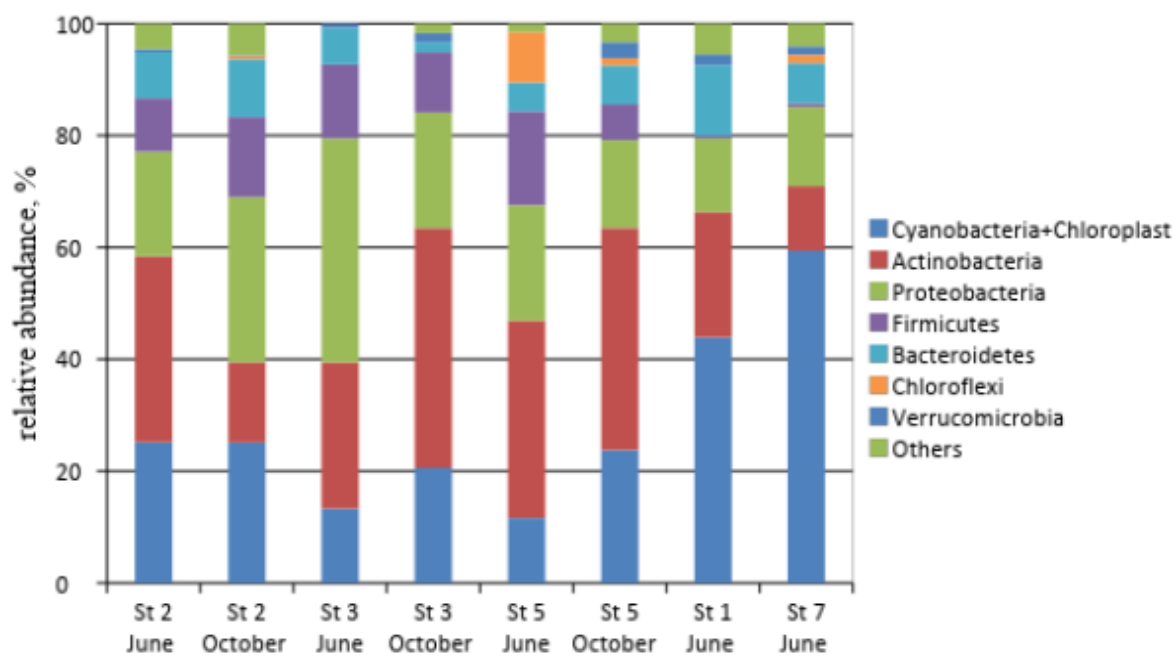

Fig. 4. The taxonomic composition of the aquatic microbial community of Lake Gusinoye at the phylum level based on high-throughput 16S rRNA gene sequencing

increased in autumn compared to summer and were lower than those reported for Lake Baikal (Parfenova et al., 2013). The dominant bacterial class was the Actinobacteria, represented by coryneform and nocardiiform bacteria. Their ecological function is primary destruction of complex organic substrates in water bodies. The Cyanobacteria class was presented mainly by the orders Chroococcales and Synechococcales. They are responsible for the production of organic substances and can be a potential source of toxins.

\section{Discussion}

Chemical composition of the water in the discharge channel and in the lake was similar. Water hardness and the amounts of dry residue indicate that this water is suitable for drinking. This conclusion is supported by balanced values of production and destruction of organic matter; at the majority of stations destruction exceeded production. The balance between production and destruction indicates ongoing processes of selfpurification in the lake. The content of dissolved minerals, determined as the sum of anions and cations, correlated with the 2016 values measured by a conductivity meter (Tsydypov et al., 2017). These data indicate an increase in the total amount of dissolved minerals from 233 to $400 \mathrm{mg} / \mathrm{L}$ and a corresponding increase in the amount of macro-component ions, in particular, sulphate and alkali metals ions, compared to the data obtained in the period before the Gusinoozerskaya TPP construction and Halbogin coal mine commencement (Borisenko et al., 1994).

The total abundance of bacteria and the abundance of organotrophic bacteria at the temperature influence point (warm water discharge) did not differ significantly from the corresponding parameters throughout the lake. No reliable correlation between the abundance of microorganisms and water temperature was found, though certain increases in the counts of bacteria were observed next to the point of warm water discharge. High counts of organotrophic bacteria were detected in the discharge channel and at the point where it enters the river, indicating the presence of easily decomposable organic compounds. It is likely that a barrier zone typical of river mouths is also formed in 
the discharge channel. Such mixing zones are characterised by increased abundance and activity of microorganisms, and within such zones, changes in water properties occur. Predominance of organotrophic bacteria and high levels of heterotrophic carbon dioxide assimilation were also detected in the barrier water mixing zone of Lake Baikal and its main tributary, the Selenga River (Maksimenko et al., 2008).

Maximum amounts of bacteria were found at the sites of anthropogenic impact near the mouths of the Zagustai and Tali Rivers. The water quality of the Zagustai River is affected by the discharge of insufficiently treated wastewaters from the Municipal Unitary Enterprise 'Gorvodokanal' in Gusinoozersk (Oshorova et al., 2004). The Tali River drainage basin pollution may be caused by the wastewaters from the Gusinoozersk Apartment Management Unit of the Gusinoozersk Garrison of the Siberian Military District of Russia, which are discharged without any treatment (Oshorova et al., 2004).

The increase in the abundance of bacteria in the discharge channel can result from the enrichment of the water with organic compounds of terrestrial and fluvial origin. A similar increase in the number of microorganisms was observed in the thermal part of the discharge channel in Kenon Lake, a natural cooler for the Haranorskaya TPP (Zabaykalsky Krai) (Matyugina, 2005). The author attributes it to the increase in the amounts of organic compounds of autochthonous (i.e., photosynthesis by phytoplankton) and allochthonous (i.e., terrigenous drainage) origin triggered by the increase in water temperature. This assumption corresponds with the thesis that presence of accessible nutrients is the main factor affecting the abundance and diversity of bacteria (Logue et al., 2012).

The patterns of taxonomic diversity of bacterioplankton at the examined stations at Lake Gusinoye were similar. A distinctive feature of the bacterioplankton in the lake was a significant proportion of the phylum Cyanobacteria, which may indicate a potential threat of a water bloom. A consistent and predictable increase in the abundance of cyanobacteria due to eutrophication of freshwater lakes and seas, especially in the coastal zone, has been described previously (Smith, 2003). It was shown that with an increase of the trophic status of freshwater lakes, significant changes in microbial community diversity occurred only at the level of individual OTUs and not at the level of phyla, which implies adaptation to specific ecological niches (Zwirglmaier et al., 2015). In contrast to our data, it was found that the dominant bacterial phyla in Lake Baikal are Bacteroidetes, Proteobacteria and Actinobacteria (Parfenova et al., 2013; Bashenkhaeva et al., 2017; Dagurova et al., 2017), which is typical of freshwater lakes (Newton et al., 2011). The difference may be attributed to the fact that the taxonomic diversity examination was restricted to the shallow water stations in the northern part of the lake subjected to thermal anthropogenic impact; therefore, further research aimed at comparing the taxonomic composition there with the control stations is essential.

\section{Conclusion}

The chemical composition of the water, the parameters of the total number of microorganisms and the abundance of organotrophic bacteria did not show significant differences between the zone of thermal influence of the TPP and the zone free of thermal influence. An increase in the number of microorganisms was observed in the thermal water discharge channel and in the vicinity of the river mouths. It is possible that a 'barrier zone', typical of river mouths which is characterised by an increase in the number and activity of microorganisms, is also formed in the discharge channel. The increase in the number of bacteria could occur due to the 
enrichment of the water with organic substances of terrestrial and fluvial origin. The patterns of bacterioplankton diversity in the parts of the lake exposed to the thermal impact were similar. A distinctive feature of the taxonomic composition of the bacterial community was the dominance of the phyla Cyanobacteria and Actinobacteria, which indicates that production and destruction processes can be intensified.

\section{Acknowledgements}

The work was carried out within the framework of the basic project of the FASO Russia 'Microbial communities of extreme natural systems: biological and functional diversity, biotechnological potential' No. AAAA-A17-117011810034-9 and with the support of the RFBR grant No. 18-44030028 .

\section{References}

Abidueva E.Yu., Dagurova O.P., Garankina V.P., Sambueva G.B. (2014) Seasonal changes of the physico-chemical and microbiological parameters of Lake Gusinoye (Western Transbaikalia). The Buryat State University Bulletin. Chemistry. Physics [Vestnik Buryatskogo Universiteta. Khimiya. Fizika], 3: $74-76$ (in Russian)

Bashenkhaeva M.V., Zakharova Yu.R., Galachyants Yu.P., Khanaev I.V., Likhoshway Ye.V. (2017) Bacterial communities during the period of massive under-ice dinoflagellate development in Lake Baikal. Microbiology, 86(4): 524-532

Borisenko I.M., Pronin N.M., Shaibonov B.B. (1994) Gusinoe Lake ecology. Ulan-Ude, Buryat Scientific Centre SB RAS, 196 p. (in Russian)

Dagurova O.P., Garankina V.P., Zaitseva S.V. (2017) The change effect of temperature and organic substances on the microbial community of the coastal zone of Lake Baikal. The Buryat State University Bulletin. Chemistry. Physics [Vestnik Buryatskogo Universiteta. Khimiya. Fizika], 1: 18-23 (in Russian)

Edgar R.C. (2010) Search and clustering orders of magnitude faster than BLAST. Bioinformatics, 26(19): 2460-2461

Edgar R.C. (2013) UPARSE: highly accurate OTU sequences from microbial amplicon reads. Nature Methods, 10: 996-998

Fadrosh D.W., Ma B., Gajer P., Sengamalay N., Ott S., Brotman R.M., Ravel J. (2014) An improved dual-indexing approach for multiplexed 16S rRNA gene sequencing on the Illumina MiSeq platform. Microbiome, 2(1): 6

Falkowski P.G., Fenchel T., DeLong E.F. (2008) The microbial engines that drive earth's biogeochemical cycles. Science, 320: 1034-1039

Khakhinov V.V., Namsaraev B.B., Barkhutova D.D., Abidueva E.Yu., Banzaraktsaeva T.G., Ul'zetueva I.D. (2005) Hydrochemical and microbiological characteristics of the Gusino-Ubukunskaya group of water bodies. Water Resources, 32(1): 73-78

Logue J.B., Langenheder S., Andersson A.F., Bertilsson S., Drakare S., Lanzén A., Lindström E.S. (2012) Freshwater bacterioplankton richness in oligotrophic lakes depends on nutrient availability rather than on species-area relationships. ISME Journal, 6(6): 1127-1136

Maksimenko S.Yu., Zemskaya T.I., Pavlova O.N., Ivanov V.G., Buryukhaev S.P. (2008) Microbial community of the water column of the Selenga River-Lake Baikal biogeochemical barrier. Microbiology, 5: 587-594

$$
-365-
$$


Martemyanov V.V., Belousova I.A., Pavlushin S.V., Dubovskiy I.M., Ershov N.I., Alikina T.Y., Kabilov M.R., Glupov V.V. (2016) Phenological asynchrony between host plant and gypsy moth reduces insect gut microbiota and susceptibility to Bacillus thuringiensis. Ecology and Evolution, 6(20): 7298-7310

Matyugina E.B. (2005) Microbial communities. Kharanorskaya Thermal Power Plant cooling pond and it's life. V.V. Kirillov (ed.) Novosibirsk, Siberian Branch of the Russian Academy of Sciences, p. 143-159 (in Russian)

Newton R.J., Jones S.E., Eiler A., McMahon K.D., Bertilsson S.A. (2011) Guide to the natural history of freshwater lake bacteria. Microbiology and Molecular Biology Reviews, 75(1): 14-49

Oshorova V.K., Oshorova T.G., Matveeva A.M. (2004) Environmental problems of the Lake Gusinoe. New technologies of extraction and processing of natural raw materials in conditions of ecological restrictions. Book of materials of the all-russian scientific conference with international participation. Ulan-Ude, p. 130-132 (in Russian)

Parfenova V.V., Gladkikh A.S., Belykh O.I. (2013) Comparative analysis of biodiversity in the planktonic and biofilm bacterial communities in Lake Baikal. Microbiology, 82(1): 91-101

Romanenko V.I., Kuznetsov S.I. (1974) Ecology of microorganisms of fresh water bodies. Laboratory manual. Leningrad, Nauka, 194 p. (in Russian)

Smith V.H. (2003) Eutrophication of freshwater and coastal marine ecosystems: a global problem. Environ. Sci. Pollut. Res. Int., 10(2): 126-139

Tsydypov B.Z., Andreev S.G., Ayurzhanaev A.A., Sodnomov B.V., Gurzhapov B.O., Batotsyrenov E.A., Pavlov I.A., Shiretorova V.G., Ulzetueva I.D., Gabeeva D.A., Radnaeva L.D., Garmaev E.Zh. (2017) Impact of discharges of Gusinoozerskaya Power Plant on thermal and hydrochemical regime of Lake Gusinoe. The Bulletin of Irkutsk State University. Series "Earth Sciences", 22: 135-150 (in Russian)

Wang Q., Garrity G.M., Tiedje J.M., Cole J.R. (2007) Naive Bayesian classifier for rapid assignment of rRNA sequences into the new bacterial taxonomy. Applied and Environmental Microbiology, 73(16): 5261-5267

Zavarzin G.A., Kolotilova N.N. (2001) Introduction to environmental microbiology. Moscow, Knizhnyi Dom "Universitet”, 256 p. (in Russian)

Zwirglmaier K., Keiz K., Engel M., Geist J., Raeder U. (2015) Seasonal and spatial patterns of microbial diversity along a trophic gradient in the interconnected lakes of the Osterseen Lake District, Bavaria. Frontiers in Microbiology, 6: 1168 